\title{
HOBBES AND THE ECONOMIC, SOCIAL AND CULTURAL RIGHTS OF THE UNIVERSAL DECLARATION OF HUMAN RIGHTS
}

\author{
JAVIER F. HERNÁNDEZ ${ }^{1}$ \\ SANTIAGO DUSSAN ${ }^{2}$
}

\begin{abstract}
This article argues that the conceptions of natural rights in Hobbes's theory and of economic, social and cultural rights in the Universal Declaration of Human Rights have three common features that serve to justify the thesis that a satisfactory order of coexistence cannot be achieved without extensive state power. Both conceptions identify rights with interests whose satisfaction is considered paramount. Both perspectives see the state as the shaper of the legal order that rights do not create. Finally, both see the state as the entity that must monopolize the management of individual interests represented in rights. This article suggests that these findings are paradoxical when confronted with the main motivation behind the drafting of the Declaration.
\end{abstract}

Keywords: Economic, social and cultural rights; natural rights; Thomas Hobbes; Universal Declaration of Human Rights; travaux préparatoires; state power.

Summary: 1. Introduction. 2. Hobbes's concept of natural Rights. 3. The COnCEPT and foundations of ECONOMic, social and cultural Rights in the UDHR. 3.1. Article 22. 3.2. Article 23. 3.3. Article 24. 3.4. Article 25. 3.5. Article 26. 3.6. Article 27. 3.7. The free and full development of personality and human dignity as pillars of the economic, social and cultural rights of the UDHR. 4. MAIN THESIS. 5. FINAL REMARKS.

\section{INTRODUCTION}

One view that has predominated among Hobbes scholars is that his theory of rights has not been important or influential for contemporary theories of rights and, therefore, that it has little to contribute to discussions on the philosophical foundations of human rights. This thesis is based mainly on the idea that Hobbesian individual rights are all 'liberty rights,' that is, rights that are not correlated with obligations on the part of others. ${ }^{3}$ If this is true, it seems clear that the Hobbesian theory of individual rights has no important connection to the current human rights discourse and to the problems surrounding their foundations. After all, the way we currently think of human rights assumes that they

\footnotetext{
${ }^{1}$ Department of Legal and Political Science, Pontificia Universidad Javeriana-Cali, Colombia (jfhernandez@ javerianacali.edu.co)

${ }^{2}$ Department of Legal and Political Science, Pontificia Universidad Javeriana-Cali, Colombia (sdussan@ javerianacali.edu.co)

${ }^{3}$ This is the thesis that, with different nuances, has been supported by authors like Gauthier (1969, p. 30), Hampton (1986, p. 51), and Kavka (1986, pp. 299-300)
} 
generate an obligation of respect on part of other individuals and particularly on part of the state (Tierney, 2008, p. 36; Green, 2012, p. 321; Gauthier, 2001, p. 267; Sreedhar, 2019, p. 142)

From different perspectives, this generally accepted view has been questioned by authors like Eleanor Curran (2002, 2013) ${ }^{4}$ and Frank van Dun (2001). Van Dun's position, as presented in his article titled 'Human Dignity: Reason or Desire? Natural Rights versus Human Rights' has attempted to demonstrate the influence and importance of Hobbes's theory of natural rights in the current human rights discourse.Van Dun argues that the concept of human rights that served as a basis for the Universal Declaration of Human Rights (UDHR or Declaration) is a legacy of Thomas Hobbes's conception of natural rights and not, as is often argued, a legacy of the classical theory of natural law and natural rights (Dun, 2001, pp. 2-3).

Van Dun bases his thesis on the similarities he finds between the concept of human rights in the UDHR and Hobbes's concept of natural rights. With regards to form, he explains that the human rights of the UDHR are 'rights to'; regarding material content, they are 'rights to desirable things,' that is, to things that most people desire (Dun, 2001, p. 12). Thus, he says, human rights appear to be specific forms of a kind of generic right to the satisfaction of desire. According to Van Dun, the socio-political approach to jurisprudence, promoted at the end of the 19th century, was a return to Hobbes's subjectivist definition of 'the natural right of man,' according to which having rights means having desires to be satisfied. This conception of rights, he argues, served as the foundation of the UDHR, which can be seen mainly in the inclusion of economic, social, and cultural rights, which are the distinctive elements of that declaration. For Van Dun, understanding social human rights ${ }^{5}$ as rights to the satisfaction of interests implies accepting that people's rights can be as unlimited as their desires and, consequently, that individual rights constitute a major source of conflict and disorder in human coexistence (Dun, 2001, p. 28). ${ }^{6}$

Van Dun's thesis is innovative and interesting from at least three perspectives. First, it challenges the traditional view that Hobbes's theory of rights has been neither relevant nor influential in the formulation of the current human rights discourse. Second, it seeks to show that Hobbes's political theory can serve as a model for understanding the nature and implications of a certain conception of human rights. Third, it also suggests that Hobbes's theory of rights can bring new analytical elements to the debate on the philosophical

\footnotetext{
${ }^{4}$ Curran has tried to show that Hobbes does have a theory of rights that generate correlative obligations, and that this theory can contribute much to contemporary theories of individual rights.

${ }^{5}$ In this article, the phrases 'social human rights' or 'social rights' are used to refer to the social, economic, and cultural rights of the UDHR.

${ }^{6}$ His criticism is directed at the way in which all human rights in the UDHR are generally conceived. However, from the examples and explanations he gives, it can be inferred that the main target of his criticism is social rights. Therefore, we take Van Dun's argument in that specific sense, that is, considering only the similarities between Hobbesian natural rights and the social rights of the UDHR.
} 
foundations of human rights. Despite the above, Van Dun's proposal remains virtually unexplored by Hobbes commentators or human rights theorists. ${ }^{7}$

This article takes the line of analysis suggested by Van Dun as its starting point. It argues that the concepts of natural rights in Hobbes's theory and of social rights in the UDHR have three common characteristics that lead to the conclusion that, without an extensive state power, it is not possible to achieve a satisfactory order of coexistence. The first significant similarity is that in both cases the rights relate to interests that, in general, human beings consider extremely valuable to satisfy. A second common feature is that, in both perspectives, the state is seen as the shaper of the legal order that the individual rights in question cannot create. Third, the State is seen by both conceptions as the entity that must monopolize the management of the individual interests represented in subjective rights.

The rest of this article is organized as follows: Section 2 presents the concept and function of natural rights in Hobbes's political theory. In Section 3, the travaux préparatoires for Articles 22 to 27 of the UDHR are explored, and the concept and rationale of social rights from the perspective of the authors of the UDHR is presented. Section 4 concludes the central argument by developing the main thesis based on an analysis of the characteristics presented in the previous two sections. Section 5 suggests, by way of a final remark, that the research findings appear to be paradoxical when contrasted with the main motivation behind the creation of the UDHR.

\section{HOBBES'S CONCEPT OF NATURAL RIGHTS}

Before examining the definition of natural rights provided by Hobbes in Leviathan, it should be said that he establishes a direct relationship between this concept and his concept of state of nature. According to Hobbes, having natural rights is one of the reasons why the state of nature is a state of war. ${ }^{8}$ Therefore, in order to clearly understand the meaning and role of natural rights in Hobbes's work, it is important to explain, first of all, precisely what the state of nature is and why he identifies it with war.

The state of nature, or 'the natural condition of mankind,' is the way in which individuals live when there is no civil state. In Hobbes's words, it is "the time men live without a common Power to keep them all in awe" (Hobbes, 1998, p. 84). ${ }^{9}$ In Chapter 13 of Leviathan, Hobbes describes this 'natural condition of mankind' in depth. He begins by stating that human beings are equal by nature. Nature, he explains, has made men

\footnotetext{
${ }^{7}$ One article by Paul Gottfried contains several points of criticism against Van Dun's argument, mainly about his idea that Hobbes' atomistic anthropology is related to the conceptual origins of the UDHR. (Gottfried, 2002). Another reference to Van Dun's thesis is made in Stephen P. Marks's article 'The Past and Future of the Separation of Human Rights into Categories' (2009, p. 225). However, that work does not include a critical analysis of van Dun's argument.

${ }^{8}$ See Finkelstein (2001, p. 333)

${ }^{9}$ (ch.13, par. 8)
} 
so physically and mentally equal that, although some may be stronger or shrewder than others, when everything is considered as a whole, these differences are not so significant as to justify an individual claiming for himself any benefit that another individual cannot also claim (Hobbes, 1998, p. 82). ${ }^{10}$

Hobbes asserts that from that natural equality in the faculties arises equality in the hope that each individual has of attaining his ends. Thus, when two men desire the same thing, which cannot be enjoyed by both, they become enemies and attempt to destroy and subjugate each other in order to satisfy their desire. Hence, each individual distrusts the other (Hobbes, 1998, p. 83). ${ }^{11}$ According to Hobbes, "from this diffidence of one another, there is no way any man to secure himself, so reasonable, as anticipation; that is, by force, or wiles, to master the persons of all men he can, so long, till he see no other power great enough to endanger him." (Hobbes, 1998, p. 83). ${ }^{12}$

Hobbes further states that men experience no pleasure, but, on the contrary, great suffering, in living together with others when there is no common power to frighten them all. This, because every individual wants his companion to hold him in as high esteem as he holds himself and will therefore be ready to injure or even destroy whoever gives him any sign of underestimation or contempt (Hobbes, 1998, p. 83). ${ }^{13}$

Hobbes concludes, therefore, that in human nature there are three main causes of discord. All three impel men to attack each other. The first is competition, which causes men to confront each other to acquire gain; the second is diffidence, which drives them to fight for safety; and the third is glory, which causes them to use violence to gain reputation (Hobbes, 1998, pp. 83-84). ${ }^{14}$ For the above, Hobbes says that the state of nature is a state of war of "every man against every man" (Hobbes, 1998, p. 84). ${ }^{15}$ He describes this condition as the most unfortunate for men, not only because it prevents cooperation and life in society, but also because those who live in it are in constant danger of dying violently (Hobbes, 1998, p. 84). ${ }^{16}$

Immediately after describing the state of nature, Hobbes introduces the concept of natural right or right of nature. Hobbes calls 'the right of nature' (jus naturale) the liberty that, in the state of nature, each individual has to use all the means and perform all the actions that he considers necessary for his preservation. According to Hobbes, given the natural equality that exists among men, it is up to each one to judge whether or not the means he uses and the actions he performs contribute to the preservation of his life (Hobbes, 1991, p. 116). ${ }^{17}$

\footnotetext{
${ }^{10}$ (ch.13, par. 1)

11 (ch.13, par. 3)

12 (ch.13, par. 4)

${ }^{13}$ (ch.13, par. 5)

${ }^{14}$ (ch.13, par. 6-7)

15 (ch.13, par. 8)

${ }^{16}$ (ch.13, par. 9)

${ }^{17}$ (ch.1, sec. 9)
} 
Hobbes, in Chapter 14 of Leviathan, defines the right of nature as follows:

THE RIGHT OF NATURE, which writers commonly call jus naturale, is the liberty each man hath, to use his own power, as he will himself, for the preservation of his own nature; that is to say, of his own life; and consequently, of doing any thing, which in his own judgment, and reason, he shall conceive to be the aptest means thereunto. (Hobbes, 1998, p. 86). ${ }^{18}$

After defining natural right as a liberty, Hobbes explains what he means by liberty:

By LIBERTY, is understood, according to the proper signification of the word, the absence of external impediments: which impediments, may oft take away part of a man's power to do what he would; but cannot hinder him from using the power left him, according as his judgment, and reason shall dictate to him. (Hobbes, 1998, p. 86). ${ }^{19}$

From both definitions, it follows that, in order to understand Hobbes's concept of natural right, it is key to first understand his concept of liberty. It is worth noting that Hobbes does not conceive the natural liberty or freedom of an individual as a de jure power, but rather as a de facto power. This power, according to the above definition, is reduced to the extent that there are impediments or obstacles external to the individual. In accordance with this explanation, Hobbes says that "a FREEMAN, is he, that in those things, which by his strength and wit he is able to do, is not hindered to do what he has a will to." (Hobbes, 1998, p.139). ${ }^{20}$

Hobbes holds that liberty properly signifies the "absence of opposition," and by opposition he means "external impediments of motion" (Hobbes, 1998, p. 139). ${ }^{21}$ Hence, he states that it is only appropriate to apply the words 'free' and 'liberty' to corporal things, for only that which is subject to motion can be subject to impediment. If freedom is, strictly speaking, corporal freedom, it can refer to both rational and irrational creatures:

For whatsoever is so tied, or environed, as it cannot move, but within a certain space, which space is determined by the opposition of some external body, we say it hath not liberty to go further. And so of all living creatures, whilst they are imprisoned, or restrained, with walls, or chains; and of the water whilst it is kept in by banks, or vessels, that otherwise would spread itself into a larger space, we use to say, they are not at liberty, to move in such manner, as without those external impediments they would. (Hobbes, 1998, p. 139). ${ }^{22}$

\footnotetext{
${ }^{18}$ (ch.14, par. 1)

19 (ch.14, par. 2)

20 (ch.21, par. 2)

${ }^{21}$ (ch.21, par. 1)

22 (ch.21, par. 1)
} 
According to Hobbes, the only thing that can reduce or limit freedom are the obstacles or impediments caused by external bodies. Thus, "when the impediment of motion, is in the constitution of the thing itself, we use not to say, it wants the liberty; but the power to move; as when a stone lieth still, or a man is fastened to his bed by sickness." (Hobbes, 1998, p. 139). ${ }^{23}$

From the above explanation, it is clear why Hobbes states that the liberty of a human being is, strictly speaking, the freedom from chains and imprisonment; that is, the power of movement that is not impeded or hindered by external bodies (Hobbes, 1998, p. 141). ${ }^{24}$ Considering that Hobbes defines natural right as a liberty, then we must understand this right as an unimpeded individual power of movement or, in his own words, as a corporal liberty. As Pettit points out, Hobbes's concept of corporal liberty refers to 'the freedom to enact the decision made,' which is different from the 'freedom to make decisions as between different options':

Hobbes distinguishes between two sorts of freedom or liberty: the freedom to make a decision as between different options and the freedom to enact the decision made. The first sort of freedom is alienated by contractual obligation, since it transfers the right of decision to another....Thus, where an agent has not alienated the right to decide, we may ascribe a contractual variety of freedom. The second sort of freedom - the freedom to enact a decision - is alienated by any physical or corporal impediment to acting on a decision....And so, where there is no such impediment to the agent's action, we may ascribe what Hobbes himself calls "corporal" freedom or liberty; this is what he takes to be freedom in the strict or proper sense. (Pettit, 2012, p. 120). ${ }^{25}$

Based on the definitions given by Hobbes, the right of nature would therefore be the corporal liberty that each individual has to use his power in the way in which his judgment and reason consider most suitable for the preservation of his own life. According to him, this right comprises any action that the individual considers appropriate in order to achieve the end of self-preservation. It is, therefore, a right to everything, even to injure or kill one's companion:

And because the condition of man...is a condition of war of every one against every one; in which case every one is governed by his own reason; and there is nothing he can make use of, that may not be a help unto him, in preserving his life against his enemies; it followeth, that in such a condition, every man has a right to every thing; even to one another's body. (Hobbes, $1998,86-87){ }^{26}$

\footnotetext{
${ }^{23}$ (ch.21, par. 1)

${ }^{24}$ (ch.21, par. 6)

${ }^{25}$ See also Pettit (2005, pp. 131-151)

${ }^{26}$ (ch.14, par. 4)
} 
If liberty is, strictly speaking, a power of movement unobstructed by external bodies (de facto power), and the right of nature is a liberty, it seems clear that the meaning attributed by Hobbes to the term 'right of nature,' or ' jus naturale,', differs substantially from the meaning this very term had in the natural law tradition before him. As Tierney explains, the phrase 'ius naturale' began to be used in a subjective sense by medieval jurists, from the twelfth century C.E. onwards, to refer to a licit claim, faculty or power inherent in every human individual (Tierney, 2004, p. 6). Thus, defined in this subjective form, a natural right or ius naturale referred to an individual licit power or faculty that did not have human law as its source, but came from natural law. As natural law was a mandate of divine authority, the natural rights derived from it generated correlative obligations of respect and compliance. When it was affirmed that an individual had, for example, the natural right to defend herself against a legal charge in a court of law, it meant that others had the correlative obligation not to impede or obstruct the performance of that action.

Contrary to what was proposed by the medieval natural law tradition that influenced authors like Francisco Vitoria (1934), Francisco Suárez (1918) and Hugo Grotius (2005), Hobbes does not conceive the right of nature as the licit power of an individual that generates correlative obligations of respect or compliance for others. As noted, Hobbesian natural right is not a de jure power, but a de facto power. Hobbes calls natural right the de facto power of an individual to carry out actions for the preservation and defense of his life. Such a 'right,' however, does not generate correlative obligations or duties for others; and is not limited by any legal restriction stemming from the natural rights of other individuals (Johns, 2009 , p. 564). If an individual has the natural right to hunt an animal for food, this in no way implies that others have an obligation not to prevent her from pursuing the animal, or a duty not to take it from her once she has it under her control. Therefore, Hobbes maintains that property does not exist in the state of nature, and a man's control over a thing lasts as long as he actually manages to keep it (Hobbes, 1998, p. 85). ${ }^{27}$

An important idea of Hobbes's approach to the right of nature is that the use of this right, when peace cannot be achieved, is a precept or general rule of reason. In other words, to achieve conservation, reason dictates that we seek peace and maintain it, which, according to Hobbes, means to create a sovereign with immense power over the subjects. However, when this purpose cannot be achieved, and we find ourselves in the natural condition, without any hope of getting out of it, reason tells us that we must defend ourselves with all the means at our disposal; that is to say, that we must use our natural right (Hobbes, 1998, p. 87).$^{28}$ Hence, in De Cive, Hobbes states that when individuals are in a state of nature it is "neither absurd nor reprehensible, neither against the dictates of true reason, for a man to use all his endeavours to preserve and defend his body and the members thereof from death and sorrows." (Hobbes, 1991, p. 115). ${ }^{29}$

What is the function of natural rights in Hobbes's argument? In other words, what is his intention behind arguing that, in the natural condition, every individual has a right

\footnotetext{
${ }^{27}$ (ch.13, par. 13)

${ }^{28}$ (ch.14, par. 4)

${ }^{29}$ (ch.1, sec. 7)
} 
to all things? Following Martinich (1995), it could be argued that Hobbes's main intention in introducing the concept of natural rights into his theory is to make even more apparent the pressing need for human beings to leave the miserable condition in which they find themselves in their natural state (Martinich, 1995, p. 265). Hobbes argues that having a right to everything not only brings no benefit to human beings, but also catalyzes conflict among them. In The Elements of Law, he states that the right of all men to all things "is in effect no better than if no man had right to any thing." (Hobbes, 1969, p. 72). ${ }^{30}$ Similarly, he says in De Cive:

But it was the least benefit for men thus to have a common right to all things. For the effects of this right are the same, almost, as if there had been no right at all. For although any man might say of every thing, this is mine, yet could he not enjoy it, by reason of his neighbour, who having equal right and equal power, would pretend the same thing to be his. (Hobbes, 1991, p. 117). ${ }^{31}$

As stated above, the right of nature does not improve the situation of individuals in their natural condition and is also a source of perpetual distrust among them. The right of nature is, therefore, one more cause of war according to Hobbes:

If now to this natural proclivity of men, to hurt each other, which they derive from their passions, but chiefly from a vain esteem of themselves, you add, the right of all to all, wherewith one by right invades, the other by right resists, and whence arise perpetual jealousies and suspicions on all hands, and how hard a thing it is to provide against an enemy invading us with an intention to oppress and ruin, though he come with a small number, and no great provision; it cannot be denied but that the natural state of men, before they entered into society, was a mere war, and that not simply, but a war of all men against all men. (Hobbes, 1991, pp. 117-18). ${ }^{32}$

For all individuals to have a right to everything is equivalent to no one having a right to anything. This is so precisely because the natural right of a human being, as a de facto power, does not produce any correlative obligation for others. No individual has the obligation or duty to respect what another decides to do or have within the bounds of her natural right. In that sense, it can be argued that the aim of Hobbes's theory of natural rights is very different from that which is normally pursued by other theories of natural rights. Theories like those of Hugo Grotius (2005) and John Locke (2003) are aimed at recognizing a sphere of legitimate action for the individual in which others cannot intervene. Thus, it is affirmed that whoever is unjustly hindered in the exercise of her right can use legitimate force to repel the aggressor or demand reparation for the damage. Therefore, conceived this way, the consequence of the attribution of rights to individuals

\footnotetext{
${ }^{30}$ (p. I, ch. 14, sec. 10)

${ }^{31}$ (ch. 1, sec. 11)

32 (ch. 1, sec. 12)
} 
is the establishment of a natural legal order. However, such an effect does not arise in Hobbes's theory, as natural rights, being de facto powers, cannot fulfilll the function of demarcating a line that separates legally permitted and prohibited conduct.

As a result, natural rights in Hobbes's theory, far from determining a natural order of coexistence between human beings, lead individuals to a situation of war of all against all, in which each individual seeks the satisfaction of their desires through violent and invasive actions. Hence, the conclusion of Hobbes's argument is that, as the natural condition of men is one of total disorder and conflict, it is absolutely necessary to escape from that state through the constitution of a body that monopolizes the power to decide in what way and to what extent the conflicting interests of individuals must be satisfied ${ }^{33}$. This body is, of course, the civil state.

\section{THE CONCEPT AND FOUNDATIONS OF ECONOMIC, SOCIAL AND CULTURAL RIGHTS IN THE UDHR}

\subsection{Article 22}

Article 22 of the UDHR aims to introduce and enhance the economic, social and cultural rights (ESCR) enshrined in the UDHR. The drafters of the UDHR included this general article in order to emphasize these new rights (which were considered less well known than civil and political rights at the time), and to draw attention to the additional efforts needed for their realization (Diller, 2012, p. 38).

At the meeting of the Commission on Human Rights on June 9, 1948, the idea of including a general and introductory article on ESCR was widely supported (E/CN.4/ SR.65). ${ }^{34}$ Malik (Lebanon) argued that "it should be clearly stated somewhere in the Declaration that it was not enough to enumerate economic and social rights, but that society itself should be of such a nature as to ensure the observance of those rights....An article to that effect should therefore be included in the section devoted to economic and social rights" (E/CN.4/SR.65/p.3). At the end of the meeting, the chairman appointed a sub-Committee to work out a special article concerning the measures to be taken in order to ensure enjoyment of economic and social rights (E/CN.4/SR.65/p.11).

The appointed sub-Committee recommended that the Commission add the following article to the end of the Declaration: "Everyone has the right to a good social

\footnotetext{
${ }^{33}$ Hobbes's idea that the state's main function is to arrange the way in which individuals can meet their needs explains why he thinks it is essential that the state supervises and, if necessary, intervenes in economic activity. As McArthur points put, "[Hobbes] thinks that economic activity plays a crucial role in determining people's well-being - and thus, ultimately, social stability - and he insists that the state must pay attention to, and be active in regulating, people's behavior in the market. He also thinks that government must be willing to expend resources in order to ensure the welfare of the people." (McArthur, 2012, p. 78)

${ }^{34}$ All references to the preparatory documents can be found on the official U.N. website: Drafting of the Universal Declaration of Human Rights (no date). Available at: https://research.un.org/en/undhr/introduction [Accessed: 21 February 2021].
} 
and international order in which the rights and freedoms set out in this Declaration can be fully realized." (E/CN.4/120). On June 10, 1948, Cassin (France), who had been a member of the sub-Committee, explained to the Commission that his delegation had proposed a second draft article addressing ESCR (E/CN.4/SR.67/p. 5), which stated: "Everyone as a member of society has the economic, social and cultural rights enumerated below, whose fulfillment should be made possible in every State separately or by international collaboration." (E/CN.4/120).

On June 14, 1948, the discussion continued on the texts submitted by the subCommittee and the French delegation. For Cassin, it was clear that the Commission had to follow the example of all recent constitutions in which ESCR were treated differently from other rights. Material assistance from the state is essential for social rights to be fully effective. According to Cassin, this was a practical difference that the Declaration could not ignore.

Finally, the Commission approved the following text: "Everyone as a member of society has the right to social security and is entitled to the realization of the economic, social and cultural rights enumerated below, in accordance with the organization and resources of each State, through national effort and international co-operation." (E/CN.4/ SR.72/p. 10). The text approved by the Commission, with some stylistic changes, became Article 20 of the draft Declaration (E/800), which was sent to the General Assembly for its consideration.

In November 1948, the content of Article 20 was resubmitted for consideration in the deliberations of the Third Committee of the General Assembly. Pérez Cisneros, the Cuban representative, criticized the part of the article that stated that ESCR would be specified in later articles of the document. According to him, this reference weakened Article 20, which deserved to stand on its own (A/C.3/SR.137/p. 498). He proposed the adoption of the amendment that his delegation had submitted, deleting the phrase "set out below" and replacing it with the phrase, "essential to their dignity and the free development of their personality." (A/C.3/232).

None of the delegations that expressly agreed with the amendment proposed by Cuba offered extensive arguments to support their positions, but briefly stated their reasons in support of the amendment. It was mentioned, for example, that such a change would lend greater strength and self-sufficiency to the article. It was also stated that the amendment would have the advantage of recalling the references to the dignity of man and the free development of his personality that appeared in other articles of the draft Declaration (A/C.3/SR.138/p. 508-509).

The Third Committee did not examine or discuss the meaning and relevance of the notions of dignity and free development of the personality that were being proposed for inclusion in Article 20. The absence of opposition shows that the drafters considered ESCR a necessary means to guarantee the individual a life of dignity and as indispensable conditions for the free development of her personality (Diller, 2012, pp. 69-70). The text was adopted and became current Article 22 of the UDHR (A/C.3/SR.138/p. 514). 


\subsection{Article 23}

For the drafters, the right to work was one of the forms in which the right to full development of the personality was expressed. They recognized that the lack of work is a problematic situation that negatively affects an individual and her family and thus decided to enshrine everyone's right to protection against unemployment. This means that other members of society and the state must take necessary measures to prevent and combat unemployment. The drafters also believed that the wages and the conditions under which work is performed must be compatible with the dignity of both the employee and her family. Hence, they enshrined every worker's right to a remuneration that ensures her and her family a dignified existence ${ }^{35}$. If the remuneration is not sufficient to achieve this purpose, it must be supplemented by other means of social protection.

In June 1947, the Drafting Committee asked René Cassin (France) to rewrite a new draft of the Declaration based on the document prepared by John Humphrey ${ }^{36}$ (Director of the UN's Human Rights Division). Cassin reformulated all the labor-related provisions and included them in his document. In the revision of his draft, Cassin proposed two articles related to the right to work that were relevant to the UDHR drafting process:

ARTICLE 29. Everyone has the right and the duty to perform socially useful work and to full development of his personality.

ARTICLE 31. Human labour is not a merchandise. It shall be performed in good conditions, and shall secure a decent standard of living to the worker and his family. (E/CN.4/AC.1/W.2/REV.2/p. 5-6).

According to Morsink (1999, p. 161), the provisions on the obligation to work and the development of personality are connected to socialist thought, which prescribes the duty of every individual to perform socially useful work. Such work contributes to the general welfare because it benefits the community in which it is performed. Similarly, when things are done right, work is an expression of the right of every person to the full development of her personality. This explains, according to Morsink, why Cassin added the reference to the right to the full development of the personality to Humphrey's text.

On December 9, 1947, in the deliberations of the Working Group on the Declaration on Human Rights, it was proposed to include in Article 29 a provision referring to the duty of the state to take measures to prevent unemployment (E/CN.4/AC.2/SR.7/p.11). Stepanenko (Byelorussia) stated that unemployment was a distressing situation that had an impact on family life and that the burden of preventing it should be shifted onto the

\footnotetext{
${ }^{35}$ Although the principle of non-discrimination had been clearly established in Article 2 of the UDHR, most delegates felt that it was necessary to include the right to equal pay for equal work, especially to ensure that women are treated equally in the workplace (E/CN.4/SR.66)

${ }^{36}$ Humphrey's draft corresponds to the U.N. Doc. E/CN.4/AC.1/3
} 
state (E/CN.4/AC.2/SR.7/p.11). The Working Group decided to adopt the following text to be incorporated as the second paragraph of Article 29: "The State has a duty to take such measures as may be within its power to ensure that all its citizens have an opportunity for useful work." (E/CN.4/AC.2/SR.7/p.13)

The Commission then considered the Lebanese delegation's proposal, which comprised adding to the first paragraph of the article on the right to work (which at that time was Article 23), a final phrase that would read: "and of protection against unemployment." (E/CN.4/SR.65/p. 8). According to Malik (Lebanon), the word 'protection' was completely unambiguous and included all measures (taken by the state, society or international cooperation) to address unemployment. He also explained that his amendment would complete the first paragraph by establishing the theory of the right to constant employment. Malik's proposal was approved by the Commission (E/CN.4/SR.65/p. 11).

As for Article 31 of the Cassin draft, the first thing to note is that in essence it is not very different from what was finally approved as the third paragraph of Article 23 of the UDHR. When the Third Committee of the General Assembly separately approved each of the four paragraphs of the article on the right to work (Article 21 at the time), but then could not agree on the adoption of the article in its entirety (A/C.3/SR.141/p. 539), it created a huge crisis. ${ }^{37} \mathrm{~A}$ sub-Committee was appointed to prepare a new text to solve this problem. Referring to the conditions under which human labor should be carried out, the sub-Committee adopted the following text as the second paragraph of Article 21: "Every one who works has the right to just and favourable remuneration, supplemented if necessary by such other means of social protection as may be required to meet the needs of his family." (U.N. Doc. A/C.3/363).

Pérez Cisneros (Cuba) objected to the arguments of some delegations which contended that Article 22 already covered the matter contained in this paragraph of Article 21. According to him, Article 22 dealt with the social security of those who, for various reasons, were unable to work. Article 21, in contrast, referred to the fact that those who do work are entitled to remuneration commensurate with their needs and those of their families. Pérez believed that Article 21 protected the dignity of the worker, who should not depend on philanthropy. For him, it was clear that some provisions should be made for those who had to support people who were too old to work, people with disabilities, or numerous children. It was society's duty to ensure "that such families, too, could lead a life compatible with human dignity." (A/C.3/SR.157/p. 681).

The Byelorussian delegation proposed introducing the following text to the second paragraph of Article 21: "Everyone who works has the right to just and favorable remuneration ensuring for his family and himself an existence worthy of human dignity, and supplemented, if necessary, by other means of social protection." (A/C.3/SR.157/p. 688). According to Kaminsky (Byelorussian S.S.R.), the wording of his amendment made it clear that the needs of the family should be included in the calculation of fair

\footnotetext{
${ }^{37}$ See Morsink (1999, p. 182)
} 
remuneration, which would serve to ensure a decent existence for the worker (A/C.3/ SR.157/p. 688). Kaminsky's proposal was approved by the Third Committee (A/C.3/ SR.157/p. 689).

Although some delegates noted that everyone's right to form and to join trade unions was already covered by the generic right to freedom of association, the idea prevailed that in view of its novelty and lack of recognition in some countries, it was vital for the Declaration to make special mention of trade union rights (E/CN.4/SR.66/p. 4).

\subsection{Article 24}

The authors of the Declaration found it necessary to recognize that the worker must be granted the right to rest and enjoy her free time, since without this right she cannot fully develop the capacities that constitute her personality. Hence, they thought it was necessary to grant her periodic paid vacations, and to ensure that the duration of her working day has a reasonable limit.

When the Third Committee was discussing the right to rest and leisure, this right was included under Article 24 as follows: "Everyone has a right to rest and leisure." (E/800). The New Zealand delegation submitted to the Third Committee an amendment to Article 24: "Everyone has the right to rest and leisure, to reasonable limitation of working hours and to periodic holidays with pay." (A/C.3/359).

Several other proposed amendments linked the right to rest with the concepts of personal development and/or self-fulfillment. For example, the delegations of the Philippines and Argentina, jointly presented the following proposal: "Everyone is entitled to due rest and leisure for his spiritual, cultural and physical well-being." (U.N Doc. A/C.3/358). ${ }^{38}$ The amendments referring to personal development were criticized by some delegations as repeating ideas related to social security and thus adding nothing new to the article (A/C.3/SR.149/p. 608-609).

Finally, the members of the Third Committee approved the New Zealand's proposal (A/C.3/SR.150/p. 614), which apart from some stylistic changes, was the same as Article 24 of the current UDHR.

\subsection{Article 25}

For the free and full development of human capabilities, the drafters concluded that it was necessary for each person and her family to have a standard of living that is adequate for their health and well-being. This right to an adequate standard of living

\footnotetext{
${ }^{38}$ Similarly, the Cuban delegation proposed the following text: "Every person has the right to leisure time and to the opportunity for advantageous use of his free time to his spiritual, cultural and physical benefit (U.N. Doc. A/C.3/261)
} 
includes the right to food, clothing, housing, medical care, and necessary social services. To prevent circumstances beyond an individual's control from stopping her from having an adequate standard of living, the authors recognized the existence of the right of every person to social security in case of unemployment, illness, disability, old age or other circumstances that cause her to lose her means of subsistence. ${ }^{39}$

In its third session, the Commission on Human Rights considered a proposal from the International Labor Organization (ILO). The proposed text was as follows: "Every one has the right to a standard of living, and to social services adequate for the health and wellbeing of himself and his family and to social security including protection in the event of unemployment, sickness, disability, old age or other lack of livelihood in circumstances beyond his control." (E/CN.4/SR.70/ p. 9).

The Chinese delegate proposed an amendment to that text, which comprised inserting the phrase "including housing and medical care, food and clothing" after the words 'social services.' (E/CN.4/SR.71/ p. 9). The Committee approved the inclusion of the complete list of rights proposed by China in the text (E/CN.4/SR.71/ p. 14)

\subsection{Article 26}

The drafters of the UDHR also believed that it is not possible to fully develop personality without education. In fact, they decided to expressly state that personality development was the goal of education. Hence, they enshrined that education should be free and compulsory at elementary level.

The final version of Article 26 of the UDHR is very similar to that stated by Humphrey in Article 36 of his $\operatorname{draft}(\mathrm{A} / \mathrm{C} .1 / 3)$. When the Working Group on the Declaration of Human Rights was discussing the right to education, A.L. Easterman, representative of the World Jewish Congress, noted that the article on education "contained nothing about the spirit governing education which was an essential element" (E/CN.4/AC.2/ SR.8/p.4). He therefore proposed adding the following article: "This education shall be directed to the full development of the human personality, to strengthening respect for human rights and fundamental freedoms and shall combat the spirit of intolerance and hatred against other nations or racial religious groups everywhere." (E/CN.4/AC.2/ SR.8/p.4). This is, in essence, the content of the current paragraph 2 of Article 26 of the UDHR. ${ }^{40}$

\footnotetext{
${ }^{39}$ The protection that the second paragraph of Article 25 enshrines for motherhood and childhood had been included since Cassin's draft (U.N. Doc. E/CN.4/AC.1/W.2/REV.2. Art. 34) and was approved by the drafters without further discussion. The Third Committee proposed the part referring to the equal social protection to which all children are entitled, regardless of whether they were born in or out of wedlock (U.N. Doc. A/C.3/344)

${ }^{40}$ Paragraph 3 of Article 26 was included as a result of a debate on the need to prevent situations in which, as in Nazi Germany, the state prevents parents from freely choosing the type of education their children receive. (A/C.3/SR.146/ p. 582).
} 


\subsection{Article 27}

The authors of the UDHR also considered it necessary to recognize the right of everyone to enjoy the arts and to participate freely in the cultural life of the community, in order to achieve the free and full development of the individual. ${ }^{41}$ It is no less necessary that the individual should have the right to benefit from the advancements of science, as her health and/or well-being may depend on them. ${ }^{42}$ In the deliberations of the Third Committee, Cassin pointed out that, although not everyone can make an equal contribution to scientific progress, it is indisputable that everyone should share in the benefits derived from it (A/C.3/SR.150/p. 619).

\subsection{The free and full development of personality and human dignity as pillars of the economic, social and cultural rights of the UDHR}

From the above study, it is clear that the rationale for the inclusion of ESCR in the UDHR is that the drafters conceived these rights as a necessary means to guarantee the individual a life of dignity and as indispensable conditions for the free and full development of her personality (Morsink, 1999, p. 212; Diller, 2012, p. 70). Thus, the phrase 'development of the personality' appears in the general article introducing ESCR into the UDHR (22) and in the article enshrining the right to education (26).

The development of the personality is also mentioned in another article of the UDHR which does not enshrine rights, but duties. This is the first paragraph of Article 29 , which states that "everyone has duties to the community in which alone the free and full development of his personality is possible." ${ }^{33}$ This text shows that the authors of the UDHR did not see human beings as individuals detached from their social context; on the contrary, they defended the interdependence between the individual and society. Just as they judged that without society an individual cannot develop her personal abilities, they also considered that an individual who receives benefits from her community has duties toward it, principally the duty to respect and ensure the fulfillment of the rights of others.

Human dignity is another of the basis for proclaiming the existence of ESCR, according to the text of the UDHR. Like the reference to the development of the personality, the reference to dignity also appears in the introductory article of ESCR (22).

\footnotetext{
${ }^{41}$ In the Third Committee, the delegations of France, Cuba, and Mexico jointly proposed adding a second paragraph to the article on the right to participate in culture. The proposed text was as follows: "Everyone has, likewise, the right to the protection of his moral and material interests in any inventions or literary, scientific or artistic works of which he is the author." (U.N. Doc. A/C.3/360). Campos Ortiz, the Mexican representative, asserted that the United Nations should use its moral authority to protect all forms of labor, both manual and intellectual. Finally, the Third Committee approved this amendment (U.N. Doc. /A/C.3/ SR.152/p. 635), which is why the second paragraph of Article 27 of the UDHR was included.

${ }^{42}$ As Morsink notes, the right to share in the benefits of science includes, among other things, the possibility of receiving affordable medicines. (Morsink, 1999, p. 219)

${ }^{43}$ The text of the DUDH can be found on the official U.N. website: Universal Declaration of Human Rights (no date). Available at: https://www.un.org/en/about-us/universal-declaration-of-human-rights [Accessed: 24 February 2021]
} 
For the drafters, the effective fulfillment of each person's social rights is vital for her living conditions to be compatible with her dignity as a human being. This idea, as seen above, is expressly stated in Article 23, which addresses the right to work (23).

Human dignity is not only mentioned in the articles that refer to ESCR, but is also found in Article 1 and in the preamble of the UDHR. Article 1 states that "all human beings are born free and equal in dignity and rights, and endowed as they are with reason and conscience, should act towards one another in a spirit of brotherhood." Similarly, the preamble refers to dignity in its first and fifth paragraphs.

The texts cited above show that the drafters considered human dignity the fundamental idea that justifies the recognition of all the rights in the UDHR, including ESCR. A reading of the travaux préparatoires ${ }^{44}$ shows that the relevance of the inclusion of the word 'dignity' in Article 1 and in the preamble was not really questioned or objected to by the drafters ${ }^{45}$. Nor was there any debate about the specific meaning that the concept of human dignity had or should have (Hughes, 2011). As McCrudden (2008) explains, it is not surprising that the idea of dignity was included without any further discussion in the text of the UDHR, especially as the expression 'human dignity' had been incorporated into the preamble of the Charter of the United Nations in 1945, and a few months later into the preamble of the international treaty creating UNESCO. Similarly, in 1944, the Declaration of Philadelphia had proclaimed the right of all human beings to "pursue both their material well-being and their spiritual development in conditions of freedom and dignity." "46 According to McCrudden (2008, p. 676), by resorting to the idea of dignity as the foundation of human rights, the authors of the UDHR were reassured that they were treading on safe ground, as this concept was frequently used in the circles that participated in the shaping of the global architecture of the UN.

\section{MaIn Thesis}

As we saw in the first part of this article, natural rights in Hobbes's theory fulfill the role of demonstrating that without the state there is no possible order of coexistence. Hobbes himself says that a universal right to all things has almost the same effects as if no one had a right to anything. Hence, universal war is the only possible outcome of the interaction among rational individuals who pursue their own survival, who are equally

\footnotetext{
${ }^{44}$ In the process of drafting the Declaration, Cassin first included the phrase 'human dignity' in the articles. Article 1 of his draft read: "All men are brothers. Being endowed with reason, members of one family, they are free and possess equal dignity and rights." (E/CN.4/AC.1/W.2/REV.2). As can be seen, this article is very similar to current Article 1 of the UDHR, particularly because both texts clearly establish that all people are equal in dignity.

${ }^{45}$ With the one exception of Te Water (Union of South Africa) who believed "there could not be, neither was there, any universal standard among the peoples of the world in their different concepts of human dignity, which were, surely, determined by the differences in religious and social systems, usages and customs." (A/C.3/SR.95/p. 92)

${ }^{46}$ The text of this Declaration can be found in ILO DECLARATION OF PHILADELPHIA (no date). Available at: https://www.ilo.org/legacy/english/inwork/cb-policy-guide/declarationofPhiladelphia1944. pdf [Accessed: 24 February 2021].
} 
vulnerable to attack by others, who compete for scarce resources, who distrust each other, and who are driven by a desire for glorification.

Hobbes seeks to refute the thesis of the previous natural law tradition, according to which there is a natural legal order of coexistence pre-existing and superior to the legal order created by political authority. By redefining the main concepts of the natural law theory (jus naturale and lex naturalis), Hobbes wants to persuade his audience that there is no such thing as a pre-state legal order. If there were a natural legal order pre-existing and superior to the state's legal order, political authority would have legal limits that it could not exceed without committing injustice. This would serve to justify, to a certain extent, the rebellion of the subjects in cases where the action of the state was considered to violate any of their natural rights. ${ }^{47}$ But this is precisely the idea that Hobbes wants to dispute, as his proposal is based on the thesis that the sovereign has no legal obligation toward the subjects ${ }^{48}$. Hence, he presents natural law and natural rights, not as concepts that create a natural legal order, but as reasons that justify the absolute necessity of a political authority that guarantees (through the management of conflicting individual interests) the preservation of the lives of the subjects and the possibility of their having a comfortable life.

Hobbes's natural rights justify state power because they show that, without the help of such power, the individual will not be able to specify objectively what she is lawfully required to do in her dealings with others, for the sake of better self-preservation, that is, in order to coexist in peace and enjoy the benefits of cooperation. Thus, the role of the sovereign will be to clearly establish the legal limits of the subjects that must be enforced in order to maintain a peaceful and prosperous coexistence. The subjective rights that create a legal order arise only when the sovereign legislates and specifically defines the legal obligations of the subjects. Therefore, it can be said that the main mission of the state is to solve an inevitable difficulty faced by individuals when they are in the state of nature, which is the inability to determine the concrete content of the mutual obligations lawfully required for peaceful coexistence.

The idea that ESCR should be recognized is often criticized on the ground that such rights fail to determine which precise social and economic claims should be granted right status (Morales, 2018, p. 257; Scott and Macklem, 1992, p. 72). The problem of the indeterminacy of social rights would consist mainly in the difficulty of identifying the

\footnotetext{
${ }^{47}$ This is, for example, the idea Locke uses in the Second Treatise to justify subjects having the right to resist the acts of the ruler when he acts as a tyrant. (Locke, 2003, pp. 188-193) (ch.18).

${ }^{48}$ Although in Hobbes's theory the sovereign has no contractual obligation to the subjects, this in no way means that some of the natural rights are not important limits of sovereign power, once the civil state has been constituted. On the contrary, Hobbes explains that natural law obliges the sovereign to guarantee the subjects the exercise of what he calls their "inalienable" natural rights. These rights are the liberties that are indispensable for survival and to live comfortably, such as the right to resist violent attack, and the rights to the use of air or water. (Hobbes, 1998, p. 222) (ch. 30, par. 1). The obligations of natural law moderate the power of the sovereign considerably, insofar as their breach is necessarily linked to terrible consequences for him: the rebellion of the subjects, civil war, and the possibility of violent and premature death. (Hobbes, 1998, p. 244) (ch.31, par. 40). But it is worth bearing in mind that in Hobbes's theory these are not legal obligations, but what we might call "prudential" obligations.
} 
specific benefits that the holder of the social right in question can demand or claim. This obstacle would logically extend to the delimitation of the correlative obligations that such rights entail for those who must respect, protect, or enforce them, and to the recognition of the type of conduct that constitutes a violation of these rights.

It might be thought that one way of attenuating the problem of the indeterminacy of social rights would be to explain the basis of these rights, that is, to set out the reasons that justify their existence and defense in some detail. However, this partial solution could not be found in the case of the ESCR in the UDHR. As was shown in the second part of this article, although the drafters formally made it clear that the foundations of these rights are the achievement of the free and full development of the personality and the assurance of an existence in accordance with human dignity, the travaux préparatoires show that there were no discussions on the concrete meaning of these notions. The UDHR establishes that there are certain rights that are vital for every human being to develop her personal abilities freely and fully, and to lead a life of dignity. However, the UDHR does not offer any criteria for identifying those personal abilities whose optimal development depends on the satisfaction of these rights. Nor does it provide hermeneutical guidelines for attributing meaning to the phrase 'human dignity' that may serve to assess whether the actual conditions of a person's life are compatible with such dignity.

The reader of the UDHR is informed in Article 22 that she has the right to demand from other members of society the procurement of certain goods or services vital to her dignity and the free development of her personality. Likewise, she is told in Article 29 that she has duties to the community, and that, in the exercise of her rights, she shall be subject only to such limitations as are necessary to ensure respect for the rights of others and to meet (among others) the just requirements of general welfare. In other words, Article 29 informs her that she also has a duty to contribute to the satisfaction of the social rights of others. On the other hand, the UDHR omits any explanation or mention of what is to be understood by development of the personality or human dignity. What should the reader of the UDHR conclude? What is she entitled to demand from other members of society? What are her duties or obligations toward others?

From this, it seems reasonable to maintain that the social human rights formulated in the UDHR do not in themselves establish a legal order, insofar as they do not provide any criterion for clearly determining the conduct that is lawfully required of individuals in their dealings with each other. A person who recognizes herself as the holder of social rights knows that she has the lawful power to demand from other members of society the goods and services that are necessary for her to develop as a person and live with dignity. Likewise, she knows that others also have a right to claim these same goods and services from her. Given that resources are limited, the problem of allocating them inevitably arises. What happens if one individual, in order to satisfy her right to education, claims the same resources that another requires to finance her right to health? The authors of the UDHR left the interpreter of the text without any hermeneutical resources to at least outline a reasonable solution to such conflicts. ${ }^{49}$

\footnotetext{
${ }^{49}$ See Glendon (1999, pp. 12-14)
} 
Seen in this light, the situation in which the holders of the social rights proclaimed in the UDHR find themselves is similar to that of individuals who, in Hobbes's theory, have a natural right to all things in the state of nature. In such a state, the rational individual described by Hobbes knows that she has a natural right to whatever she judges necessary for her preservation. However, the individual recognizes that others also have the same right as she does. Given the inevitable scarcity of resources, what should happen when two individuals pursue the same object, but both cannot enjoy it? Can natural rights serve as a criterion for resolving the conflict and finding a 'just' distribution of the disputed goods? Hobbes takes care to show that natural rights cannot fulfill such a purpose, as their main effect is not to order coexistence, but to aggravate mutual distrust and perpetuate the state of war between individuals. To solve the problem of the absence of a natural legal order, Hobbes proposes the constitution of the civil state: a power that monopolizes the creation of law and establishes the conduct required of individuals in their mutual dealings.

Like Hobbes, the drafters of the UDHR saw state action as the main means to overcome the absence of legal order generated by the formulation of social rights in the document. From their perspective, states have the primary obligation to guarantee the social rights of their citizens. The deliberations on Article 22 of the UDHR indicate that the delegates considered that a fundamental difference between civil and political rights and social rights was that the fulfillment of the latter required material assistance from the state. However, it was also clear to them that each state should have the power to autonomously decide how it would design its economic policy and distribute resources to fulfill that objective..$^{50}$ This is why Article 22 of the UDHR states that the satisfaction of the social rights of each individual should be obtained taking into account "the organization and resources of each state". The UDHR thus entrusts states with the task of creating the legal order that individuals must observe in order to achieve their social rights. For example, the state authorities must specify the amount that each citizen is obliged to contribute as taxes for the support of public health or education services, and the specific percentage that must be allocated to the fulfillment of each of these rights. Similarly, the same authorities will determine the quantity, quality, or specific form of each good or service that each individual is entitled to demand from other members of society.

If the UDHR charges states with the function of determining the legal obligations that their citizens have with respect to the fulfillment of social human rights, it seems clear that states will also have the power to attribute a concrete meaning to the notions of 'free and full development of the personality' and 'human dignity'. Thus, state authorities will be primarily responsible for answering in detail questions such as: What are the personal abilities whose development must be protected and stimulated and to what extent? What does it mean to say that the human dignity of all people should be respected? What are the material conditions necessary for a citizen to lead a dignified existence?

Considering that the ability to define the way in which a society's wealth should be redistributed to ensure the full attainment of social human rights implies a high degree of

\footnotetext{
${ }^{50}$ See Morsink (1999, p. 209)
} 
central planning, it is plausible to affirm that the UDHR also gives states great power to control, even through coercive means, the way in which citizens can effectively exercise their right to property. This right, also recognized in Article 17 of the UDHR, must be considered by state authorities when establishing the conduct required of citizens in their reciprocal dealings with each other. Thus, the state will define the extent to which a person's right to property can be limited (via taxes, for example), in order to finance the cost of fulfillling her social rights and those of other members of the community.

The above shows that the conceptions of natural rights in Hobbes's theory and of social rights in the UDHR share three characteristics that serve to justify the idea that it is not possible to achieve a satisfactory order of human coexistence without the very broad power of state intervention. The first significant similarity is that in both cases the rights are related to interests that, in general, human beings consider extremely important to satisfy. In the case of Hobbes's theory, natural rights encompass whatever the individual deems necessary for her self-preservation. In the case of the UDHR, social rights encompass everything that is necessary for the individual to develop freely and fully and to lead a life with dignity. Another similarity is that, in both conceptions, the concrete content of the mutual legal obligations that must be taken into account to achieve peace, or to achieve an order that guarantees the full development and dignity of individuals, remain undetermined for individuals until the state intervenes and establishes the due conduct between them. This is equivalent to saying that, in both perspectives, the state is seen as configuring the legal order that the individual rights in question do not create. This generates the third and most important similarity: both conceptions see the state as the entity that must monopolize the management of individual interests represented in subjective rights. From this point of view, the state must have the power to intervene in the economy and to decide how and to what extent individual interests and desires can be satisfied, as they are in a permanent state of tension and conflict because of the competition for scarce resources.

\section{Final REMARKS}

The idea that the UDHR's conception of social rights, just like Hobbes's conception of natural rights, gives the state a vast power to intervene in individual decisions seems somewhat paradoxical when set against the main objective that motivated the creation of the UDHR.

The purpose of drafting the UDHR was to create a universal moral code that would serve to prevent the recurrence of atrocities and barbaric acts such as those perpetrated by totalitarian Nazi and Fascist states during World War II. Historical events such as the Holocaust demonstrated the great threat that could be posed to human beings by a state with excessive power over their lives and freedoms. To achieve this goal, which was subsequently enshrined in the second clause of the Preamble of the Declaration, the idea was to create a document that would function as a navigation chart to ensure that no institution or individual would violate the inalienable rights of people around the world ever again. At the first session of the Drafting Committee, Wilson, the representative of the United Kingdom, emphasized the importance of the historical situation in which this collegiate body had met: "It was one, he said, where Germany and other enemy Countries 
during the war had completely ignored what mankind had regarded as fundamental human rights and freedoms. The Committee met as a first step toward providing the maximum possible safeguard against that sort of things in the future." (E/CN.4/AC.1/SR.7/p. 5).

If the main objective of the UDHR was to establish a charter of individual rights that would serve as a limit to state power, whose excesses had resulted in acts abhorrent to the conscience of humanity, it seems partly contradictory that the document should have given states themselves the leading role in determining the specific content and manner of fulfillment of an important group of human rights. Moreover, the fact that the drafters refrain completely from attaching a specific meaning to the phrases 'human dignity' and 'free development of personality' meant that it was also left to the states to define the foundations of all the rights contained in the document, whether socioeconomic, civil or political. The findings of this study highlight the difficulty of reconciling the following two assertions: 1. The fundamental objective of the UDHR is to keep state power in check and to prevent abuses against the individual. 2. The UDHR attributes to the state the powers to define the concrete meaning of the foundations of human rights, to define the specific limits of social rights, and to intervene in the economy to decide how resources should be allocated for the fulfillment of all the human rights contained in the document.

\section{REFERENCES}

Curran, E. (2002) 'Hobbes's theory of rights - A modern interest theory', Journal of Ethics, 6(1), pp. 63-86. https://www.jstor.org/stable/25115715

Curran, E. (2013) 'An Immodest Proposal: Hobbes Rather than Locke Provides a Forerunner for Modern Rights Theory', Law and Philosophy, 32(4), pp. 515-538. https://doi.org/10.1007/s10982-012-9149-y

Diller, J. (2012) Securing Dignity and Freedom Through Human Rights': Article 22 of the Universal Declaration of Human Right. Leiden: Brill | Nijhoff.

Dun, F. van (2001) 'Human Dignity': Reason or Desire? Natural Rights versus Human Rights', Journal of Libertarian Studies, 15(4), pp. 1-28.

Finkelstein, C. (2001) 'A Puzzle About Hobbes on Self-Defense', Pacific Philosophical Quarterly, 82(3-4). https://doi.org/10.1111/1468-0114.00131

Gauthier, D. (1969) The Logic of Leviathan. Oxford: Clarendon Press.

Gauthier, D. (2001) 'Hobbes: The Laws of Nature', Pacific Philosophical Quarterly, 82(3-4), pp. 258-284. https://doi.org/10.1111/1468-0114.00128

Glendon, M. A. (1999) 'Foundations of Human Rights: The Unfinished Business', The American Journal of Jurisprudence, 44(1).

Gottfried, P. (2002) 'Locke, Hobbes, and The UD: Comment on Van Dun', Journal of Libertarian Studies, 16(3), pp. 83-87.

Green, M.(2012) ‘Hobbes and Human Rights’, in Lloyd, S.A. (ed.) Hobbes Today. Cambridge: Cambridge University Press. https://doi.org/10.1017/CBO9781139047388.020 
Grotius, H. (2005) The Rights of War and Peace. Edited by R. Tuck. Indianapolis: Liberty Fund Inc.

Hampton, J. (1986) Hobbes and the Social Contract Tradition. Cambridge: Cambridge University Press. https://doi.org/10.1017/CBO9780511625060

Hobbes, T. (1969) The Elements of Law, Natural and Politic. London: Frank Cass \& Co.

Hobbes, T. (1991) Man and Citizen (De Homine and De Cive). Edited by B. Gert. Indianapolis: Hackett Publishing Company.

Hobbes, T. (1998) Leviathan. Edited by J. C. A. Gaskin. Oxford: Oxford University Press.

Hughes, G. (2011) 'The Concept of Dignity in the Universal Declaration of Human Rights', Journal of Religious Ethics, 39(1). https://doi.org/10.1111/j.1467-9795.2010.00463.x

Johns, C. (2009) 'The Grounds of Right and Obligation in Leibniz and Hobbes', The Review of Metaphysics, 62(3). https://www.jstor.org/stable/40387825

Kavka, G. S. (1986) Hobbesian Moral and Political Theory. Princeton: Princeton University Press.

Locke, J. (2003) Two Treatises of Government and A Letter Concerning Toleration. Edited by I. Shapiro. New Haven: Yale University Press.

Marks, S. P. (2009) 'The Past and Future of the Separation of Human Rights into Categories', Maryland Journal of International Law, 24(1), pp. 208-241. https:// digitalcommons.law.umaryland.edu/mjil/vol24/iss1/19

Martinich, A. . (1995) A Hobbes Dictionary. Cambridge: Blackwell.

McArthur, N. (2012) “"Thrown amongst Many”: Hobbes on Taxation and Fiscal Policy', in Lloyd, S. A. (ed.) Hobbes Today. Cambridge: Cambridge University Press. https://doi.org/10.1017/CBO9781139047388.011

McCrudden, C. (2008) 'Human Dignity and Judicial Interpretation of Human Rights', The European Journal of International Law, 19(4), pp. 655-724. https://doi.org/ 10.1093/ejil/chn043

Morales, L. (2018) 'The Discontent of Social and Economic Rights', Res Publica, 24, pp. 257-272. https://doi.org/10.1007/s11158-017-9353-6

Morsink, J. (1999) The Universal Declaration of Human Rights: origins, drafting and intent. Philadelphia: University of Pennsylvania Press.

Pettit, P. (2005) 'Liberty and Leviathan', Politics, Philosophy \& Economics, 4(1), pp. 131-151. https://doi.org/10.1177/1470594X05049439

Pettit, P. (2012) 'Freedom in Hobbes's Ontology and Semantics: A Comment on Quentin Skinner', Journal of the History of Ideas, 73(1), pp. 111-126.

Scott, C. and Macklem, P. (1992) 'Constitutional Ropes of Sand or Justiciable Guarantees? Social Rights in a New South African Constitution', University of Pennsylvania Law Review, 141(1), pp. 1-148. 
Sreedhar, S. (2019) 'Interpreting Hobbes on Civil Liberties and Rights of Resistance', in Interpreting Hobbes's Political Philosophy. Cambridge University Press, pp. 141-155. https://doi.org/10.1017/9781108234870.009

Suárez, F. (1918) Tratado de las leyes y de Dios legislador. Madrid: Reus.

Tierney, B. (2004) 'The Idea of Natural Rights-Origins and Persistence', Northwestern Journal of International Human Rights, 2(1). https://scholarlycommons.law .northwestern.edu/njihr/vol2/iss $1 / 2$

Tierney, B. (2008) 'Historical Roots of Modern Rights: Before Locke and After', in Frohnen, B. and Grasso, K. (eds) Rethinking Rights: Historical, Political, and Philosophical Perspectives. University of Missouri Press, pp. 34-57.

Vitoria, F. (1934) Commentarios a la Secunda Secundae de Santo Tomas. Madrid: Asociación Francisco de Vitoria.

Received: July $1^{\text {st }} 2021$

Accepted: September $3^{\text {rd }} 2021$ 